\title{
1. Social innovation in Southern European cities: local governance and citizen practices - Spanish cities as an illustration
}

\author{
Marisol García Cabeza, Ana Belén Cano-Hila \\ and Marc Pradel-Miquel
}

\section{INTRODUCTION}

What do the socially innovative experiences that focus on social exclusion dynamics in Barcelona, Bilbao, Madrid, Zaragoza and in Athens, Naples, Lisbon and other Southern European cities have in common? And what are the peculiarities of social innovation in each city? To what extent do the emergence and development of social innovation that touches on citizens' aspiration to be participants of society fit within the local governance model? The literature on social innovation in cities around the world shows how rich and diverse are the concrete innovative experiences in cities (Moulaert et al., 2013; BEPA, 2014; Howaldt et al., 2013, 2019). Part of this wide literature also shows that each city has a specific governance model that supports or inhibits social innovation and that may be conditioned by the multi-level governance framework in which local institutions operate (Moulaert et al., 2013; Oosterlynck et al., 2013; Eizaguirre et al., 2012; Kazepov, 2010). This book claims that the experiences of social innovation in Southern European cities - whether carried out by citizens, civil society associations or social movements with or without the support of institutions - have both unique and common traits. To start with, there are the common characteristics of their national welfare systems that have developed over time into particular local welfare constructions in which social innovation springs up. To consider social innovation in cities with regard to path-dependent mechanisms of welfare distribution implies acknowledging important aspects of social reality that can best be comprehended as a process (Pierson, 2000, 264). Second, cities have a history of civil society organizations, particularly the non-profit sector 
that provides social welfare in cooperation with the local institutions, some of which have been innovative in the past and allow room for new innovations. Here again, some specific characteristics of the cooperation with institutions have developed in the Southern European countries that reinforce our focus on governance (Andreotti et al., 2012). Third, there is a historical dynamism in social innovation. Socially innovative initiatives that flourished in the 1970s in cities, often in neighbourhoods with strong communities, became incorporated in local policies and some of the leaders of those initiatives were co-opted by administrations. Over the last decade a new wave of citizen practices has produced new innovations related to the current socio-economic and governance trends.

The financial and economic crisis of 2008 and the austerity programmes that followed gave a new impulse to social innovation in Southern European cities. Citizens and local institutions in Southern European cities have had to adapt to the consequences of private and public decisions concerning their lives and welfare that had been taken at the national level and elsewhere. Constitutional changes were introduced in some European Union (EU) member states to compel austerity in response to the crisis of public debt. These top-down changes were considered necessary by governments to restore the confidence of international financial markets in these countries' economies. In some cases, these EU-imposed changes involved a comprehensive system of tutelage with pressure for expenditure cuts in exchange for access to finance. The consequences of austerity led citizens in general and urban communities in particular to demonstrate ample social creativity. The strong role that family and community solidarity has traditionally had in the provision of welfare in Southern European countries was activated with renewed strength to face unemployment, housing evictions and cuts in social services. Moreover, organized citizens created new social and economic spaces of innovation to counteract social exclusion that occurred as a consequence of the crisis and the austerity programmes. In addition, the consequences of austerity programmes did not leave many citizens, particularly young citizens, politically indifferent. They created new political spaces and, in some instances, called into question both substance and frameworks of existing arrangements. The renewed push towards social innovation after the 2008 crisis in Southern European cities was often an attempt at social change, with a reawakened sense of social justice, a concept that had been sidelined by the notion of social cohesion.

Why write a book with a focus on social innovation, governance and citizen practices in Spanish cities? We argue in this introductory chapter that the socially innovative practices that are taking place in urban Spain have a lot in common with the experiences in other Southern European cities. Our argument is based on the literature on social innovation in cities of the other Southern European countries and also on the accumulated knowledge of the 
characteristics as well as the hazards that Greece, Italy, Spain and Portugal have experienced over the decades in building welfare regimes and refining their democracies (the journal South European Society and Politics documents this). The commonalities of these countries have been revived in a rather negative image with the widely used acronym of PIGS. ${ }^{1}$ The term originated within economics but was used even by distinguished social scientists, politicians and policy-makers, not always critically, in the aftermath of 2008 focusing on their debt accumulated over the years while overlooking similar conditions in Northern Europe. Southern European countries were pressed by the Troika (European Commission, European Central Bank, International Monetary Fund) to impose significant pro-cyclical fiscal consolidation measures. Austerity policies were enforced under 'memoranda of understanding' individually formulated for each of the four countries and monitored by these supranational institutions.

The peculiarities of the Southern European welfare-state systems and the vulnerability experienced by their societies in periods of economic crisis in general and particularly in the aftermath of 2008 deserve attention in this chapter because the combination of structural factors and contingencies is central to many of the social innovation experiences and citizen practices aimed at dealing with social exclusion. It is important to recognize that from 2008 new patterns of social exclusion in cities have emerged in addition to the traditional ones. The protagonists in these new categories of the socially excluded may have higher-education degrees, a long working career or a previously stable community life in a neighbourhood. One might well argue that this was hardly the first crisis ever. However, the peculiarities of this context deserve particular attention seeing how the transformation of cities is closely related with their welfare restrictions and with responses of their citizens.

It is well known that cities have experienced social transformation in their local economies and in their position in national and international contexts. In the four Spanish cities analysed in this book, as illustrations of many other Southern European cities, the industrial local economies have been partly restructured in favour of the service economy. All four have entered the global circuit using branding to get competitive advantage in the global economy: Barcelona and Bilbao are widely mentioned as success stories of urban regeneration from their industrial past, using architectural design and branding as instruments of their competitive strategies. Madrid - as the capital of Spain - concentrates on financial and cultural infrastructures as well as a diversified modern service economy. The three cities are attracting international investment and increasing numbers of international tourists. Zaragoza, while maintaining its industrial character, organized an International Exposition in 2008 capturing public investment for urban regeneration as the other three cities had done. At the same time, these cities fomented social spaces of vulnerability 
and urban poverty. Increased unemployment and precarious employment have resulted in the so-called 'new poverty'. The introduction of new national labour laws and agreements between 2010 and 2013 in the four countries (Moreira et al., 2015) expanded the new precariat (Standing, 2014). As a result of the new regulations in the labour markets of these countries lay-offs were eased and the power of labour undermined. This paved the way for badly paid employment that generated social exclusion. Meanwhile, in some of the neighbourhoods of these countries' cities the double blow of unemployment and housing crisis collided with cutbacks in financial and human resources in welfare and social services. Spanish cities deserve special attention because the economic and debt crisis became particularly acute with the bursting of the housing bubble (García, 2010).

Spanish cities illustrate citizen responses as do other large cities in Southern Europe. Changes in welfare regulation and diminishing income opportunities led large sectors of a generation of young people to perceive their career prospects as seriously compromised. Already bitter at the limited job opportunities this young generation frequently showed, both locally and nationally, its disappointment with mainstream politics and refrained altogether from voting in electoral contests (OECD, 2016, 129-31). In Southern European cities the disappointment with issues such as the new poverty, the deteriorated working conditions of welfare-state professionals and the frustration of sectors of the middle classes took political form and materialized as occupations of squares and public spaces. Many buildings were also occupied in response to housing needs or to claim cultural spaces for social participation. These citizen manifestations contributed to the reconfiguration of public spaces and led to new conversations in the public sphere. Participation in society became a rallying cry for a young generation that had (and to this day has) difficulties to enter the labour market and whose 'autonomous' status is the euphemism for what is seen as the new exploited class (Harvey, 2012). In reaction, members of this generation created new spaces of social innovation to combat the social exclusion associated with poverty. The new social spaces combined cultural creativity with associative life, sometimes claiming old buildings in the centre of cities, sometimes in the form of open market spaces with alternative local currencies to reinforce community life. The responses were in many instances new practices in which urban citizens showed considerable creativity in designing and putting into effect horizontal solidarity projects (Moulaert et al., 2013).

The early anti-austerity political platforms in cities in the Southern European countries often developed into political movements. In early 2011 citizens took over city squares in Barcelona, Athens, Lisbon, Madrid and many other places. Although their grievances were often specific and local, one common cry was 'they do not represent us'. In the subsequent years new social movements 
appeared with some of them turning into political parties (Movimento 5 Stelle in Italy; SYRIZA in Greece; Podemos in Spain; Geraçao à Rasca, Indignados Lisboa, Democracia Verdadeira Ja! in Portugal). A common element of the political agenda of each social movement and new political party was their stance against austerity as an expression of neoliberal capitalism which had inflicted damage on their social base (Della Porta, 2015, 35). These movements demonstrated a capacity to move up from the local (sometimes from neighbourhoods) to the level of national and European parliaments with agendas that not only aimed at preserving and reconquering social protection but also challenged the ways of operating of the established political class. The new parties entered political competition in local, regional and national elections and got involved in governing. As a result, new urban programmes that focused on redistribution in favour of the vulnerable sectors of society were introduced with uneven impact in cities.

We return to the main focus of our book with a reflection on the impact on local governance of the emerging socially innovative initiatives and citizen practices before and after the 2008 crisis. In our research we have observed how welfare provision from below was redefined by the new initiatives based on the principle of social justice and the value of human dignity. We describe cases that questioned ways of defining social assistance in cities. Also, some social platforms vindicated rights to services and challenged ways of operating of private corporations. These socially innovative organizations also questioned traditional ways of cooperation between civil society organizations and local institutions. In other words, they questioned the governance of local (and sometimes national) social policy. By challenging old ways of cooperation these organizations created new ways of bottom-linked practices with the hope of making a contribution to governance innovation. We started our investigation by asking: how has this wave of initiatives had an impact on local governance in terms of citizen involvement and of the provision of services? And to what extent have the new citizen practices innovated the governance models of their own organizations and of their local institutions?

\section{SOCIAL INNOVATION: A FOCUS ON CITIZEN PRACTICES, SOCIAL JUSTICE AND CITIZENSHIP}

Social innovation is a historically used concept and has gained even more significance since the end of the twentieth century (Godin, 2015; Moulaert et al., 2013; Moulaert and MacCallum, 2019). Part of this growing significance is due to the assimilation of the concept in the public policies of institutions (from supranational bodies to city administrations). At the European level a large number of programmes have proliferated, including research and development programmes on social innovation since the 1990s, involving 
both horizontal networks and public bodies. EU institutions have invoked social innovation as a way to find new answers to emerging problems linked to technological change, ageing, unemployment, migration and climate change in a context of financial constraints (BEPA, 2014) $\square$. The European Commission has launched policy programmes including social innovation as a key strategy in different fields, such as employment and social services. Many of the EU directives have promoted the activation of the local level in the construction of innovative social services as part of the principle of subsidiarity. EU social policy programmes are particularly relevant to Southern European cities, given the limited financial capacity of city councils and the top-down austerity policies (Andreotti and Mingione, 2016).

How social innovation is promoted by the EU institutions has been questioned because of the risk that social innovation gets decoupled from the specific contexts in which it flourishes. Also, ready-made policies emanating from institutions may not leave time and space for reflection by the innovative actors on the ground. This criticism coincides with the overall view that finds a parallel development between social innovation as a policy instrument and the neoliberal policies and austerity enforced by European institutions (Fougère et al., 2017). A dominant approach understands social innovation as a new way to provide social care in substitution of, or complementing, a weakening of welfare states. Social actors can find new responses and communities can organize collectively to provide services and cover needs in novel and flexible ways, as new forms of business can appear. This approach tends to focus on social businesses overlooking the role that, for example, social movements can have as key actors in social innovation. This perspective tends to understand social innovation in economic terms and as an instrument to ensure models of 'caring liberalism' (Moulaert et al., 2017, 19) $\square$ that allow better and new forms of involvement by the community in solving problems. Moreover, in social terms it is linked to conceptualizations of community development, social capital and the commitment for social cohesion, often overlooking conflictive views about how to go about it (Eizaguirre et al., 2012, 2009) $\square$.

Critics have seen this approach to social innovation as another example of the exercise of neoliberalism, and as the rolling out of austerity urbanism (Peck, 2012). Austerity urbanism consists in the 'dumping of responsibilities, risks, debts and deficits of the crisis to the local scale', transforming the financial crisis into an urban crisis and forcing local governments to follow strict rules having to choose between a particular kind of development or default. In this scenario, innovative initiatives from civil society to cope with social problems or urban development can be read as part of the neoliberal strategy and as forms of collaboration with the withdrawal of the state from social policy (Rosol, 2012). We think, however, that linking social innovation to the rolling out of neoliberalism is too simplistic, as social innovation can also play 
a counter-hegemonic role by advancing other models of economic development and governance. For example, a widely cited approach (Moulaert et al., 2007, 2013), based on extensive research on social innovation, emphasizes the changing relations of power between actors, the role of innovative actors that emerge from society (urban communities and organized citizens), the strengthening of rights for excluded sectors of the population and the efforts aimed at the enactment of new rights. The virtue of this approach consists in pointing out the constructive role that social innovation can play in reinforcing the role of social policies emanating from the state. The dichotomy top-down/ bottom-up often present in critical approaches is overcome by registering the potential of bottom-linked governance of social innovation in social policy (Moulaert et al., 2019).

There are multiple visions of social innovation and its role in relation to governance, with different approaches in terms of agency and processes of innovation. Social innovation and public social policy have the common objective of changing the life chances, burdens and aspirations of citizens and perhaps producing social change. In their efforts, actors (organized citizens and mainly public institutions) have developed four different discourses concerning social innovation. These are: Voluntarism, Social Movement, New Public Management and New Public Governance (Hulgård and Ferreira, 2019, 26-9). The Voluntarism discourse echoes the entrepreneurship approach articulated by Joseph Schumpeter in which the individual entrepreneur has a predominant role in innovating the economy while allowing little room for public policy. The Social Movement discourse gives community and collective actors a predominant role, whether as members of civil society or as civic advocates in larger organizations. In both cases active members seek some form of institutionalization of their practices, either in the form of social enterprises or through an impact on legislation widening social and political rights. The New Public Management discourse conceives of innovation as introducing management practices of the private sector in public institutions, such as competition and commercial practices. Finally, the New Public Governance discourse puts the emphasis on partnerships between the public sector, civil society and private actors. Of these four discourses only the Social Movement discourse stresses the collective action of citizens. The Social Movement discourse related to social innovation was heralded by analysts who often assumed that social movements direct their actions with a view to social justice. And this is our position in this book. However, history informs us that this is not always the case and some social movements have advanced discourses to restrict the rights of minorities, citizens who are culturally different or political adversaries. The recent revival of nationalist movements in well-established democratic countries is a case in point. 
Since social innovation as an analytical concept is under construction it is still difficult to delineate the contours of its definitions in order to gain conceptual robustness. This is one of the reasons why more empirical research is needed. Instead, numerous normative conceptions of social innovation are invoked by the actors involved in 'innovative' practices, but also by analysts applying the different approaches mentioned earlier. There is a danger of confusion. We are not free from this danger. It may be argued that some normative position is required as a point of departure. In this book we understand social innovation as a method of social inclusion at the local level directed at citizens who are socially excluded. We give priority to social exclusion rather than poverty as an analytical variable because it incorporates community as well as individual resources or lack of resources and because it focuses on social relations and institutional barriers to access and memberships (Silver, 2019; Cano-Hila, 2019). Most of the cases analysed in Chapters 4 to 8 in this book address social exclusion issues. The participants in the socially innovative practices we analyse work hand in hand with the less fortunate members of society. But we also see social innovation as a by-product of social and political participation involving the formulation of new claims for extending social rights as well as the defence of existing rights. In this instance the innovative practices of citizens aim to change the existing modes of governance of policy. In this second conception social innovation enters into dialogue with the concept of citizenship in general and with the idea of urban citizenship. Particularly so when social innovation takes place in cities and engages with local institutions in an attempt to influence local governance (Beauregard and Bounds, 2000; Isin and Nielsen, 2008; García, 2006). Like urban citizenship, social innovation has gained significance in cities with social transformations and the transformation of the welfare state in Southern European societies. As pointed out earlier, Southern European municipalities have been limited in their efforts to deliver resources to meet social needs by an often defective multi-level governance coordination in social policy and also by the last decade of austerity policies imposed on them from above. These two aspects have stimulated the emergence of specific collective social innovators in their cities (Vaiou and Kalandides, 2016; Semprebon and Vicari Haddock, 2016). In order to better explain social innovation in Spanish cities we have adopted the approach that sees social innovation as a response to unmet social needs by the market or the state and which has civil society and other forms of organized citizens and communities as central actors who create initiatives that aim to contribute to the satisfaction of those needs. These organized citizens may engage with local institutions in a bottom-linked way to influence local governance (Moulaert et al., 2013) or may choose to remain critical at the borders of the public sphere (Eizaguirre et al., 2012). The two research questions we explore in this book are: (1) Does bottom-linked cooperation between actors 
of social innovation and local institution help to consolidate the innovative initiatives and to accomplish their objectives? (2) Can socially innovative organizations influence and modify local policy orientation and governance?

\section{SOCIAL TRANSFORMATIONS, LOCAL WELFARE SYSTEMS AND SOCIAL INNOVATION}

Social transformations were already under way when the financial and economic crisis exploded in 2008. By then, demographic changes had led to a growth in the numbers of citizens in need of attention, such as the ageing population with their increasing need for health and social care. Other demographic changes, such as higher divorce rates or the increasing number of single-person and single-parent households had weakened the family as a reliable support group for the elderly and the dependent even in Southern European societies, where family solidarity remained strong (Mingione and Benasi, 2019; Body-Gendrot et al., 2012). Greece, Spain, Italy and Portugal had experienced an increase in social inequality in the years 2009-14 with a polarization pattern in employment (see Chapter 3 in this book). New labour market regulations and flexibilization affected mainly young cohorts, women and immigrants but also challenged the traditional bread-winner model, where the male head provided income and related benefits to the family unit. As mentioned in the introduction of this chapter, the 2008 economic crisis caused large job losses in low- and mid-level occupations causing working- and middle-class unemployment and impoverishment. The austerity policies that followed also created job losses in the public sector and contributed to multiply precarious income opportunities with widespread part-time and short-term contracts. Moreover, the austerity plans forced the national welfare states of Greece, Portugal, Italy and Spain to undergo what some authors call 'distributive recalibration'. In the area of employment, for example, recalibration in protection-related policies meant a change in the difference in quality of provisions between traditional 'insiders' and 'outsiders' in the labour market. ${ }^{2}$ Differences between these two groups decreased because the former became less protected (Pavolini et al., 2015; Moreira et al., 2015).

It is well known that the relative power of trade union organizations has diminished in most advanced democracies in parallel with changing regulation in labour markets with the neoliberal turn. This has affected redistributive policies and has damaged the texture of social citizenship (Atkinson, 2015; Crouch and Keune, 2012). However, there are variations in European societies as to how governments have addressed globalized socio-economic effects. These variations are related to the national institutional responses of each society and to the resilience of the previously established social contracts. How inequality has increased after redistributive policies were implemented gives 
an indication of those variations. In the EU, inequality of disposable income after redistribution varied considerably at the end of the hardest years between Scandinavian countries, on the one hand, and Southern and the majority of Eastern European countries, on the other, with intermediary levels in countries like Germany, Austria, France and the Netherlands (Eurostat, 2016). There is a strong parallel between the lower levels of social inequality and the most resilient welfare states. Cano-Hila and her fellow authors show in Chapter 3 in this book the growth in social inequality measured in Greece, Portugal and Spain and to a lesser degree Italy in the period 2009-14. These authors also show the impact of national growth in social inequality and poverty in the four Spanish cities that illustrate our analysis, where social exclusion dynamics are related not only to market behaviour, but also to social policy provisions.

\section{Welfare Restructuring, Local Welfare Systems and the Relevance of Social Innovation}

Social needs increased and diversified for the reasons mentioned so far. At the same time the public institutions responsible for the provision of welfare had to cope with restricted budgets. Even before 2008 the neoliberal ideology had strongly affected welfare systems with financial restrictions that brought about the externalization of care from the public sector to civil society groups or to privately provided care. Welfare states have restructured in a variety of ways, although there are discernible common trends that affect the provision of social services (Martinelli, 2017, 391-408). Martinelli summarizes common European trends: (1) 'general disengagement of the state' from the direct provision of in-kind services in favour of outsourcing or cash transfers. In Southern European countries, the tendency of state withdrawal from some social services has been practically total as a result of austerity. (2) In a downward 'vertical re-articulation of responsibility', local governments have become more responsible to provide services. This decentralization of services provision has a longer history in Northern countries, where the development of multi-level governance matched the move towards financial decentralization. In Southern European countries, however, the more recent downward transfer of responsibility to the local level in service provision was not smoothly accompanied by financial decentralization. It is this particular context that has stimulated the appearance of bottom-up initiatives involving the third sector and civil society to fill the gap not covered by the state. (3) A 'horizontal re-shuffling of responsibility' in which the private sector has gained space of action and where recommunitarization has been encouraged. In the case of Southern European countries this horizontal transfer of responsibility has involved a refamilization. These common trends between Northern and Southern countries in Europe attributed by Martinelli and others to the 
neoliberal turn have facilitated some convergence between policy practices. However, the implementation of austerity policies especially in the Southern countries has led to an overall weakening of social services provision to meet the needs of vulnerable citizens in these countries (Martinelli et al., 2017).

The previous concluding remarks from an extensive secondary research ${ }^{3}$ partly explain why local welfare systems have been forced to introduce changes. Here we concentrate on the decentralization of responsibilities and on what Martinelli calls 'horizontal re-shuffling of responsibility'. First, decentralization and the rescaling of welfare provision and governance have been widespread. Nonetheless the regulatory framework remains in the hands of the central states. Exceptions are Italy and Spain, where regulations have shifted to intermediate, i.e. regional authorities. Even in these countries national regulations shape and limit some policy areas, such as employment and housing (Kazepov, 2010; Cano et al., 2017). But what do we mean by 'local welfare systems'? We borrow the definition from Andreotti et al. (2012, 1926): 'dynamic processes in which the specific local socio-economic and cultural conditions give rise to different arrangements of formal and informal actors, public or not, involved in designing and implementing welfare resources'. Local welfare systems have been deployed in policy areas such as work activation directed at the unemployed and at recipients of social assistance. We want to emphasize their importance in the policy framework of maintaining social cohesion in cities. This is why some of the cases that illustrate our city analysis in Chapters 5 to 8 relate to the activation paradigm.

The impact of activation and its governance locally and its critique cannot be covered in this introduction (see van Berkel and Borghi, 2008). It is worthwhile to mention, however, that involving many actors in activation policies as part of the local welfare system creates a variety of processes and outcomes. We have seen in our research that the financial capacity of local governments is uneven in Spain, making some administrations more able than others to provide services, which can result in differences in citizenship entitlements according to place of residence. In other words, rich cities and regions will be able to provide more policy resources (whether delivered by state agents or by civil society organizations) whereas poor cities and regions would do even worse comparatively. Thus, local welfare systems may become a hindrance to universalism (Andreotti et al., 2012, 1934-5).

A more optimistic view would see the stronger role of local welfare systems as an opportunity for institutional innovation. The argument has been that social risks that emerge locally can best be treated by actors that also operate locally and who may be more sympathetic to innovations as they are more accustomed to govern social policy together with non-state actors (Oosterlynck et al., 2016, 4-6). In fact, social innovation has to some extent contributed to open up the centralized and bureaucratized field of social policy. The high proportion of 
non-state actors in social innovation creates more flexible responses to adapt to new social risks. Moreover, the opening up of welfare institutions to incorporate innovative actions in the social policy field by civil society is related both to the subsidiarity principle and to the multi-level governance paradigm in the EU (Kazepov, 2010). Also, the fact that the local gets a stronger role in social policy opens up the urban public sphere for claims and actions of citizens who become social innovators (García, 2006). There is, however, a contradiction in bottom-up socially innovative initiatives: while actors challenge established social welfare in social protection policy, at the same time these initiatives seek to, and often do, benefit from the instruments of public welfare policies (Oosterlynck et al., 2016, 11). Finally, Martinelli $(2017,396)$ calls for caution in denominating all local initiatives emanating from civil society and from citizen action as socially innovative. She recommends distinguishing between those initiatives that merely substitute the retrenchment of the welfare state and those initiatives that develop projects with a potential for the empowerment of the socially excluded and for social transformation.

\section{SOCIAL INNOVATION AND THE ROLE OF CIVIL SOCIETY IN GOVERNANCE}

Debates on social innovation and governance are often comprised within the wider question of the role of civil society in governance. Since the 1990s the development of multi-level governance has involved civil society actors in policy-making. How governance has been implemented and which actors have been privileged by institutional policy-makers has been at the centre of governance analysis. Authors have underlined the tensions in governance models based on consensus between public, private and societal actors (Swyngedouw, 2005; Geddes, 2006). They raise the key issue of how civil society is involved in governance and which specific actors of civil society participate. Approaches based on caring associated with neoliberalism give a central role to civil society in the provision of services in substitution to redistributive policies, whereas critical approaches focus on fostering the role of citizens in governance through their involvement in the design and implementation of programmes with the aim to strengthen existing public policies (Moulaert et al., 2017).

Two important points emerged from empirical research in European cities. The limited impact and sustainability of social innovation if it is not accompanied by public action (Martinelli, 2013; Martinelli et al., 2017) $\square$ and the weak capacity of social innovative actors to transform the governance of social policy at least locally without institutional support. A complementary point is to what extent the combination of the two are required to foster social justice through redistributive programmes (Martinelli, 2013; Martinelli et al., 2017). 
Initiatives emerging from civil society cannot provide effectively universal services or resources without the support of the local government action of backing similar initiatives where the social fabric has less cultural and financial resources, for example in neighbourhoods that concentrate social vulnerability. Without this support and redistributive policies, social innovation by itself may only lead to the reinforcement of territorial inequalities (Blanco et al., 2016) $\square$.

This analysis is particularly relevant for Southern European cities, where the local welfare systems relied on the role of family and on community solidarity in combination with action by civil society groups and by the local administration (Andreotti and Mingione, 2016). As said before, austerity policies from above have impacted on such systems in a negative way. At the same time they have prompted a new wave of innovations and community building with citizens taking the initiative in their own neighbourhoods. In many Spanish cities the neighbourhoods have once more become spaces for political and social organization, continuing a long tradition started in the 1970s. Social exclusion problems related to housing or lack of social services are concentrated in specific neighbourhoods facilitating the expansion of organization of local groups to face these problems. An example is one case that had a large impact, it started in a neighbourhood in Barcelona and was able to scale up from a local to a national social movement: the 'Platform of Mortgage Victims' (De Weerdt and García, 2016). These forms of organization are local but they are often connected and related with other groups and social movements that operate in networks beyond neighbourhood and cities and that are a part of a wider anti-austerity movement.

In Spain, but also in the other Southern European countries (Zavos et al., 2018), the recent wave of innovations fits in a more general framework of claims for greater action from the state to strengthen social policies and to consolidate social rights under attack. In this context, socially innovative initiatives play out in parallel to the emergence of political movements in seeking to change the ways of policy-making (Hadjimichalis, 2018). The arrival of anti-austerity local governments in many cities in 2015 in Spain shows this commitment and has paved the way for new forms of collaboration between civil society and local administration (Blanco and Gomà, 2019). However, many of these local governments lost power in the local elections of 2019, including the cities of Madrid and Zaragoza, in favour of conservative governments. The local elections in 2019 were distinguished by political division within the anti-austerity left-wing parties and platforms and the consolidation of a new cycle in Spanish politics marked by the rise of nationalisms. The commitment of the new local governments to the recently established forms of collaboration between social actors promoting social innovation and local administrations is not yet clear. 
It is important to recognize how neighbourhoods figure again as spaces of resistance to austerity and creativity, reinvigorating local communities. It is well known that neighbourhoods are places that define the immediate social world of individuals and where the interactions between citizens and institutions are fundamental for the structuring of opportunities for participation in society, especially for young people (Cano-Hila et al., 2018). Neighbourhoods have become spaces for social innovation as practices of solidarity and support networks permeate daily life. In this regard there has been a rediscovery of the neighbourhood as the arena where policy is applied and also where collective organization happens (Brokking et al., 2017). Indeed, resistance practices have traditionally occurred at the neighbourhood scale, and the recent economic crisis has reinforced this. Neighbourhoods offer material and institutional resources, including infrastructures and services, as well as immaterial ones, such as a sense of belonging, identity or reputation. Efforts to overcome social exclusion have enabled local communities to strengthen social relations between neighbours and to improve self-organization. Social initiatives in a particular locality can express a 'sense of place' (Pradel-Miquel and Martí-Costa, 2012) as a central element of such action. Examples of this can be self-managed social centres, neighbourhood social markets and community initiatives against unemployment.

Research on social innovation has linked the development of socially innovative initiatives with the existing social and political capital in neighbourhoods, and with their civic capacity (Blanco and León, 2017; Parés et al., 2018). Important though this is, we should not underestimate the relevance of informal practices based on reciprocity and everyday forms of resistance (Scott, 1989) in very deprived neighbourhoods, where civic and political capital may be weaker (Pradel-Miquel, 2017). Besides, the question of organizational capacity of communities in neighbourhoods brings us back to the issue of territorial inequalities and to the need for policies that enable neighbourhoods with less resources, including cultural capital and organization capacity, to develop innovative responses. Once again we think the expansion of bottom-linked practices across the city could be taken more seriously by local policy-makers.

In this book we explore the relations (whether of collaboration or conflict) between the administration and citizens' initiatives, mainly in Spanish cities. We advance two hypotheses. The first is that a greater collaboration between actors of social innovation and local administrations consolidates these initiatives. This collaboration allows for greater material and technical resources, grants sustainability and enhances impact in terms of social inclusion. A second hypothesis is that stronger dependence of the innovative measures from organized citizens on the local administration can lead to a degree of institutionalization that limits the combination of flexibility and effectiveness 
that the measure showed at the beginning. For this reason, many initiatives want to keep their autonomy although this does not prevent them from seeking alternative ways for collaboration with local institutions. We show some examples that illustrate how both hypotheses can be confirmed.

The concept of bottom-linked governance of social innovation summarizes how social actors develop forms of internal organization and establish relations to other actors, including public institutions, which allow for sustainability and autonomy of the initiative through negotiation and collaboration (García Cabeza and Pradel-Miquel, 2019). These forms of collaboration provide public backing for the initiative in terms of resources or technical support and includes the initiative in wider programmes or policies of the city council, making it more sustainable and improving its effects in terms of social inclusion. The local administration can put in motion new policy programmes inspired by the innovative initiative, helping or fostering similar initiatives in other neighbourhoods or calling local actors into action. Bottom-linked initiatives allow for greater impact, durability and regulation because of the support from the administration, but at the same time can profit from the autonomy of citizens (who are often people suffering exclusion themselves) and their first-hand knowledge of specific problems and social reality.

Thus, socially innovative initiatives can be analysed not only in terms of their impact in solving the coverage of an unmet need, but also in terms of their impact transforming governance and empowering citizens in the development of new responses. Beyond the objectives of the initiatives, civil society can also promote innovations in how they relate with city authorities, and create new mechanisms for negotiation, cooperation and coordination with the local administration. This process of co-creation can result in stronger social rights as new policy instruments for the generalization and development of innovative initiatives are created. Local administrations can also have a role in this process, through generating new policy instruments or creating more informal ways of collaboration that allow for the sustainability of citizen initiatives.

The relations between local administration and social actors developing socially innovative initiatives are dynamic and change through time, depending on the orientation of the different actors, the institutional context and the capacity to negotiate and to find agreement. Research has shown that agreement between social actors and local administration sometimes happens after a period of opposition and collective mobilization (Vitale, 2007; Eizaguirre et al., 2012, 2011) $\square$. The ideological positions of actors and their objectives are key elements for understanding the dynamics of collaboration and conflict. As noted earlier in this chapter, different conceptions of social innovation entail different governmental approaches to the participation of civil society in governance, and define the terms of participation. We can find differences between neoliberal approaches and more public-oriented approaches within 
the same country but also variations in the different policy fields and in the type of involvement of different actors with different objectives within cities. For example, some initiatives operating in the area of social and cultural participation in neighbourhoods may be excluded from decisions concerning the cultural economy of cities (García et al., 2015).

At the same time, socially innovative initiatives may intend to remain at the margins of political institutions or prioritize horizontal organization over formal collaboration with the administration, which might require a change in their legal status. In terms of values, some initiatives focus on complementing existing policies and the actors developing them accept the existing governance framework, and therefore participate in existing mechanisms. Other initiatives put social justice at the forefront and make this a central part of their identity, which can lead to reluctance or even refusal to engage with existing governance frameworks in favour of different relations with the administration. For these initiatives, long-term impact is often more relevant than solving immediate problems (Vicari Haddock and Tornaghi, 2013).

Finally, the dynamics between citizen groups and local administration occur in a wider framework of relations and against a historical background of collaboration and conflict. This path dependency partly determines the character of the innovations in each city and in the local social policy framework. Local welfare systems as well as both formal and informal mechanisms of local governance are the context for the interaction of actors. As we will see, there are relevant differences between cities, depending on their trajectory. The existing local welfare systems frame the possibilities for action and determine the degree of innovation particularly in policies dealing with social exclusion.

Bottom-linked initiatives can result in bottom-linked governance with partnerships between actors whose influence differs in reach and level. The involvement of social actors and the administration may transform social relations and political practices at different scales (Moulaert et al., 2019). Southern European cities have been a laboratory for this; with the financial crisis in 2009 their citizen initiatives became more political with a greater emphasis on social justice and on the need for new governance arrangements. The opposition to austerity measures often led to claims for new governance arrangements. Also, informal practices sometimes evolved into formal political demands, for instance against cuts in gas and electricity or against mortgage evictions (Pradel-Miquel, 2017). With the emergence of new governing bodies willing to enhance the role of citizens in governance, new relationships were effectively established.

Many socially innovative initiatives from both citizens and the administration have proposed new forms of relations between civil society and the state through the strengthening of commons-based management instead of public-private partnerships. Local initiatives often claim a greater role for the 
community in the development of policies and in management, trying to create new collective responses to different issues such as housing, employment or the provision of basic services. Inspired by the writings of Elinor Ostrom (2018 [1990]) $\square$ and the further development of her ideas on the urban commons (Harvey, 2012), this approach seeks to establish new forms of public-common partnerships, in which local communities manage a resource with support from the local administration. The commons also appear at the core of policy programmes of new political platforms in Spanish cities. These programmes seek to strengthen participation and involvement of citizens in political life in different ways: some local administrations have developed new legislation and innovative processes to promote public-common partnerships and have supported the involvement of citizens in such practices (Castro-Coma and Martí-Costa, 2016). In Bologna, for instance, the 'Regulation between Citizens and the City for the Care and Regeneration of the Urban Commons' was passed in 2014, even though local social movements were against it, demanding more bottom-up participation (Bianchi, 2018). In Barcelona, the political platform that took power in 2015 gave a central role to the commons in their programme and in the image of the platform, the concept being included in the name itself: Barcelona en Comú (Eizaguirre et al., 2017). The city council of Barcelona has developed different initiatives in the promotion of the commons, for instance the development of policy instruments to create new partnerships between citizens and administration in the provision of certain services (Sánchez Belando, 2017).

\section{ORGANIZATION OF THE BOOK}

This book analyses the role of social innovation in governance in four Spanish cities as an illustration of what has happened in Southern European cities. By taking a close look at this part of Europe we aim to encourage similar publications presenting comparative cases in the region. We make some comparisons between the cases we present and the cases analysed by other authors in Greece, Italy and Portugal, but not in any systematic way. In the four Spanish cities, we take into consideration the relevance of institutional and multi-level governance contexts, the diversity and strength of civil society actors and social movements in each city and the ideological position of the local government. The first part of the book presents the methodology we have used (Chapter 2), the context of exclusion in which social innovation takes place (Chapter 3) and a comparative view of the four cities (Chapter 4). For every city we have chosen relevant experiences of social innovation in the fields of employment, resources and participation and have analysed their impact on the model of local governance, in terms of new policies, new mechanisms of decision making or new regulatory frameworks. The emergence of these 
initiatives must be framed in the context of exclusion dynamics presented in Chapter 3. As we will see, these dynamics differ not only between European countries but also within Spain.

Chapter 4 presents a comparative analysis between social innovation initiatives in the Spanish cities. The four cities can be analysed comparatively in various ways. We can compare Madrid as the capital city with the other three cities. As the capital of Spain, Madrid has a distinctive governance framework with different relations with regional and national governments, whereas the other three cities have had to find models for competitiveness and cohesion with less support from central government. We can also compare the two largest cities, Madrid and Barcelona, with the two large-to-medium-sized cities of Bilbao and Zaragoza, where civil society is less diverse. A third comparison is between institutional contexts and governance models, comparing Madrid, characterized by a more market-oriented approach, with Barcelona, Bilbao and Zaragoza that have more of a social-cohesion approach. Since the 1990s, Madrid has developed a market-oriented governance approach, with a minor role for civil society, and has given priority to private actors and to certain organizations, such as the Catholic Church, in the work of social cohesion. In Barcelona, however, there is a strong model of participation of civil society concerning culture, urbanism or social cohesion, even though in other decisions participation is weaker. Barcelona has transformed its economic model linked to an urban transformation based on consensus building and strategic planning, a model that has had influence in the governance models of Zaragoza and Bilbao.

Chapters 5 to 8 present the in-depth analysis of each city from a governance perspective. Each chapter relates the governance context with specific initiatives, comparing some of the cases with similar initiatives in other Southern European contexts. We have chosen to focus on socially innovative initiatives in the areas of employment, participation and resources. In Chapter 5 Ana Belén Cano-Hila and Marc Pradel-Miquel analyse the case of Barcelona, which has a long tradition of institutionalization of civil society actions to reinforce social cohesion through the development of a governance model based on strategic planning. The crisis brought a new wave of socially innovative initiatives that sought to find new ways to relate to the administration as regards their autonomy while ensuring their continuity. The arrival into power of an anti-austerity government in 2015 facilitated the experimentation by both the local administration and the civil society in new forms of relationship. In Chapter 6 Santiago Eizaguirre Anglada incorporates the features of the special fiscal regime of the Basque Country which gives more autonomy and resources to municipalities. Nevertheless, having more resources available for organizations involved in social innovation does not mean a passive role of the civil society but better opportunities for the development of their initi- 
atives and the reinforcement of local welfare, strengthening the conditions for social innovation. This enabling policy context is also possible given the long political stability in the city government and the environment of collaboration between administrative levels. The analysis of Madrid in Chapter 7, developed by Fernando Díaz Orueta and María Luisa Lourés Seoane, stands in contrast with Barcelona and Bilbao as the governance model developed since the 1990s was based on a market-oriented approach and a residual role for civil society in the institutional work of social cohesion. In this context, the crisis brought new forms of solidarity and collective organization which questioned not only the effects of the crisis but also the neoliberalization of the city. The election of an anti-austerity government in 2015 allowed for certain experimentation in new forms of relation between civil society and local government, although this was difficult due to the lack of experience and policy instruments to do so. Finally, in Chapter 8 Marisol García Cabeza and Lídia García Ferrando analyse social innovation and governance in Zaragoza. There, we find a governance model that involves a diversity of civil society groups and local organizations in the provision of welfare. The case is similar to Barcelona in the institutionalization of civil society initiatives, but in Zaragoza we find a more compact civil society. With the crisis, a new wave of actors and initiatives emerged; however, they tended to integrate into already established mechanisms of participation and decision making, and to collaborate with actors and initiatives that had emerged in previous periods of crisis back in the 1980s and 1990s. We finally consider the role of social innovation against social exclusion in Southern European cities and its potential impact in local welfare systems and in the defence of citizenship.

\section{NOTES}

1. The acronym was also used including Ireland as PIIGS. The acronym may have had a negative impact on the response of financial markets towards these countries during the crisis. https://blogs.lse.ac.uk/europpblog/2014/12/12/the-piigs -acronym-had-a-clear-negative-impact-on-the-market-treatment-of-the-piigs -countries-during-the-crisis/, accessed 25 October 2019.

2. This distinction between these two categories is commonly used in the labour market literature to refer to those who have access to relatively stable jobs and can build working careers ('insiders') and those who have temporary jobs that sometimes do not entail economic rights given the shortage of employment contracts ('outsiders').

3. COST Action IS1102, SO.S. Cohesion: 'Social Services, Welfare State and Places', coordinated and chaired by Flavia Martinelli. 


\section{REFERENCES}

Andreotti, A. and E. Mingione (2016), 'Local welfare systems in Europe and the economic crisis', European Urban and Regional Studies, 23(3), 252-66. doi: 10.1177/0969776414557191

Andreotti, A., E. Mingione and E. Polizzi (2012), 'Local welfare systems: A challenge for social cohesion', Urban Studies, 49(9), 1925-40. doi: 10.1177/0042098012444884

Atkinson, A.B. (2015), Inequality: What can be done?, Cambridge, MA: Harvard University Press.

Beauregard, R.A. and A. Bounds (2000), 'Urban citizenship', in E.F. Isin (Ed.), Democracy, Citizenship and the Global City, London: Routledge, pp. 243-56.

Bianchi, I. (2018), 'The post-political meaning of the concept of commons: The regulation of the urban commons in Bologna', Space and Polity, 22(3), 287-306. doi: $10.1080 / 13562576.2018 .1505492$

Blanco, I. and R. Gomà (2019), 'Nuevo municipalismo, movimientos urbanose impactos políticos', Desacatos, 61, 56-69.

Blanco, I. and M. León (2017), 'Social innovation, reciprocity and contentious politics: Facing the socio-urban crisis in Ciutat Meridiana, Barcelona', Urban Studies, 54(9), 2172-88. doi: 10.1177/0042098016659044

Blanco, I., H. Cruz Gallach, R. Martínez Moreno and M. Parés i Franzi (2016), 'El papel de la innovación social frente a la crisis', Ciudad y Territorio Estudios Territoriales, 48(188), 249-60.

Body-Gendrot, S., M. García and E. Mingione (2012), 'Comparative social transformations in urban regimes', in A. Sales (Ed.), Sociology Today: Social transformations in a globalizing world, London: SAGE, pp. 359-78.

Brokking, P., M. García, D. Vaiou and S. Vicari (2017), 'Housing and neighbourhood: Basic needs, governance and social innovation', in F. Martinelli, A. Anttonen and M. Mätzke (Eds), Social Services Disrupted: Changes, challenges and policy implications for Europe in times of austerity, Cheltenham, UK and Northampton, MA, USA: Edward Elgar Publishing, pp. 342-62.

Bureau of European Policy Advisers (BEPA) (2014), Social Innovation: A decade of changes, Luxembourg: Publications Office of the European Union.

Cano, A., M. García and M. Pradel (2017), 'Barcelona: Policies for social cohesion in the context of urban competitiveness', in R. Cucca and C. Ranci (Eds), Unequal Cities: The challenge of post-industrial transition in times of austerity, Abingdon: Routledge, pp. 115-37.

Cano-Hila, A.B. (2019), 'Urban poverty', in A.M. Orum (editor in chief), D.R. Judd, M. García Cabeza, P. Choon-Piew and B. Roberts (Eds), The Wiley-Blackwell Encyclopedia of Urban and Regional Studies, Hoboken: Wiley-Blackwell, pp. 2476-83.

Cano-Hila, A.B., M. Sabariego and P. Ruiz Bueno (2018), 'Youth participation in Spanish urban periphery: Its concept, spheres and conditioning factors', Youth Voice Journal, 8, 1-42. https://youthvoicejournal.com/2018/11/22/ana-belen-cano-hila -marta-sabariego-puig-and-antoni-ruiz-bueno-2018-youth-participation-in-spanish -urban-periphery-its-concept-spheres-and-conditioning-factors/

Castro-Coma, M. and M. Martí-Costa (2016), 'Comunes urbanos: De la gestión colectiva al derecho a la ciudad', EURE. Revista latinoamericana de estudios urbano regionales, 42(125), 131-53. doi: 10.4067/S0250-71612016000100006 
Crouch, C. and M. Keune (2012), 'The governance of economic uncertainty: Beyond the "new social risks" Analysis', in G. Bonoli and D. Natali (Eds), The Politics of the New Welfare State, Oxford: Oxford University Press, pp. 45-67.

De Weerdt, J. and M. García (2016), 'Housing crisis: The Platform of Mortgage Victims (PAH) movement in Barcelona and innovations in governance', Journal of Housing and the Built Environment, 31(3), 471-93.

Della Porta, D. (2015), Social Movements in Times of Austerity: Bringing capitalism back into protest analysis, Cambridge: Polity.

Eizaguirre, S., M. Pradel, A. Terrones, X. Martinez-Celorrio and M. García (2012), 'Multilevel governance and social cohesion: Bringing back conflict in citizenship practices', Urban Studies, 49(9), 1999-2016.

Eizaguirre, S., M. García and M. Pradel-Miquel (2017), 'Citizenship practices and democratic governance: "Barcelona en Comú" as an urban citizenship confluence promoting a new policy agenda', Citizenship Studies, 21(4), 425-39. doi: $10.1080 / 13621025.2017 .1307609$

Eurostat (2016), Gini Coefficient of Equivalized disposable income: EU.SILC survey. http://ec.europa.eu/eurostat/web/products-datasets/-/tessi190

Fougère, M., B. Segercrantz and H. Seeck (2017), 'A critical reading of the European Union's social innovation policy discourse: (Re)legitimizing neoliberalism', Organization, 24(6), 819-43.

García, M. (2006), 'Citizenship practices and urban governance in European cities', Urban Studies, 43(4), 745-65.

García, M. (2010), 'The breakdown of the Spanish urban growth model: Social and territorial effects of the global crisis', International Journal of Urban and Regional Research, 34(4), 967-80.

García Cabeza, M. and M. Pradel-Miquel (2019), 'Bottom-linked approach to social innovation governance', in P. Van den Broeck, A. Mehmood, A. Paidakaki and C. Parra (Eds), Social Innovation as Political Transformation: Thoughts for a better world, Cheltenham, UK and Northampton, MA, USA: Edward Elgar Publishing, pp. 107-8.

García, M., S. Eizaguirre and M. Pradel (2015), 'Social innovation and creativity in cities: A socially inclusive governance approach in two peripheral spaces of Barcelona', City, Culture and Society, 6(4), 93-100.

Geddes, M. (2006), 'Partnership and the limits to local governance in England: Institutionalist analysis and neoliberalism', International Journal of Urban and Regional Research, 30(1), 76-97. doi: 10.1111/j.1468-2427.2006.00645.x

Godin, B. (2015), Innovation Contested: The idea of innovation over the centuries, London: Routledge.

Hadjimichalis, C. (2018), Crisis Spaces: Structures, struggles and solidarity in Southern Europe, London: Routledge.

Harvey, D. (2012), Rebel Cities: From the right to the city to the urban revolution, London: Verso.

Howaldt, J., R. Kopp and M. Schwarz (2013), Social Innovations as Drivers of Social Change: Tarde's disregarded contribution to social innovation theory building, Dortmund: Sozialforschungsstelle Dortmund, TU Dortmund University. www.transitsocialinnovation.eu/content/original/Book\%20covers/Local\%20PDFs/ 99\%20SF\%20Howaldt\%20Kopp\%20and\%20Schwarz\%20Social\%20innovations \%20as\%20drivers\%20of\%20social\%20change\%202013.pdf

Howaldt, J., C. Kaletka, A. Schröder and M. Zirngiebl (2019), Atlas of Social Innovation, Vol. 2: A World of New Practices, Munich: Oekom Verlag. 
Hulgård, L. and S. Ferreira (2019), 'Social innovation and public policy', in J. Howaldt, C. Kaletka, A. Schröder and M. Zirngiebl (Eds), Atlas of Social Innovation, Vol. 2: A World of New Practices, Munich: Oekom Verlag, pp. 26-9.

Isin, E.F. and G.M. Nielsen (2008), Acts of Citizenship, London: Zed Books.

Kazepov, Y. (Ed.) (2010), Rescaling Social Policies: Towards multilevel governance in Europe, Farnham: Ashgate.

Martinelli, F. (2013), 'Learning from case studies of social innovation in the field of social services: Creatively balancing top-down universalism with bottom-up democracy', in F. Moulaert, D. MacCallum, A. Mehmood and A. Hamdouch (Eds), The International Handbook on Social Innovation: Collective action, social learning and transdisciplinary research, Cheltenham, UK and Northampton, MA, USA: Edward Elgar Publishing, pp. 346-60.

Martinelli, F. (2017), 'Social services disrupted: Changing supply landscapes, impacts and policy options', in F. Martinelli, A. Anttonen and M. Mätzke (Eds), Social Services Disrupted: Changes, challenges and policy implications for Europe in times of austerity, Cheltenham, UK and Northampton, MA, USA: Edward Elgar Publishing, pp. 391-408.

Martinelli, F., A. Anttonen and M. Mätzke (Eds) (2017), Social Services Disrupted: Changes, challenges and policy implications for Europe in times of austerity. Cheltenham, UK and Northampton, MA, USA: Edward Elgar Publishing.

Mingione, E. and D. Benasi (2019), 'El modelo de bienestar en la Europa del Sur y la lucha contra la pobreza y la exclusión social', Panorama social, 29, 9-23.

Moreira, A., Á.A. Domínguez, C. Antunes, M. Karamessini, M. Raitano and M. Glatzer (2015), 'Austerity-driven labour market reforms in Southern Europe: Eroding the security of labour market insiders', European Journal of Social Security, 17(2), $202-25$.

Moulaert, F. and D. MacCallum (2019), Advanced Introduction to Social Innovation, Cheltenham, UK and Northampton, MA, USA: Edward Elgar Publishing.

Moulaert, F., F. Martinelli, S. González and E. Swyngedouw (2007), 'Introduction: Social innovation and governance in European cities: Urban development between path dependency and radical innovation', European Urban and Regional Studies, 14(3), 195-209. doi: 10.1177/0969776407077737

Moulaert, F., D. MacCallum, A. Mehmood and A. Hamdouch (Eds) (2013), The International Handbook on Social Innovation: Collective action, social learning and transdisciplinary research, Cheltenham, UK and Northampton, MA, USA: Edward Elgar Publishing.

Moulaert, F., A. Mehmood, D. MacCallum and B. Leubolt (2017), Social Innovation as a Trigger for Transformations: The role of research, Luxembourg: Publications Office of the European Union. http://dx.publications.europa.eu/10.2777/68949

Moulaert, F., D. MacCallum, P.V.d. Broeck and M. García (2019), 'Bottom-linked governance and socially innovative political transformation', in J. Howaldt, C. Kaletka, A. Schröder and M. Zirngiebl (Eds), Atlas of Social Innovation, Vol. 2: A World of New Practices, Munich: Oekom Verlag, pp. 63-6.

Oosterlynck, S., Y. Kazepov, A. Novy, P. Cools, E. Barberis, F. Wukovitsch, T. Sarius and B. Leubolt (2013), The Butterfly and the Elephant: Local social innovation, the welfare state and new poverty dynamics, Antwerp: Herman Deleeck Centre for Social Policy, University of Antwerp. www.centrumvoorsociaalbeleid.be/ImPRovE/ Working\%20Papers/ImPRovE\%20WP\%201303_2.pdf

Oosterlynck, S., A. Novy, Y. Kazepov, G. Verschraegen, T. Saruis, F. Colombo, P. Cools, R. Cucca, B. Leubolt and C. Bweinzieri (2016), Towards a More Effective 
Governance of Socially Innovative Policies: First insights from the case studies (ImPRovE Working Paper, 16/11), Antwerp: Herman Deleeck Centre for Social Policy, University of Antwerp. http://improve-research.eu/

Organisation for Economic Cooperation and Development (OECD) (2016), Society at a Glance 2016, Paris: OECD Publishing. www.oecd-ilibrary.org/social-issues -migration-health/society-at-a-glance-2016_9789264261488-en

Ostrom, E. (2018 [1990]), Governing the Commons: The evolution of institutions for collective action, Cambridge: Cambridge University Press.

Parés, M., I. Blanco and C. Fernández (2018), 'Facing the great recession in deprived urban areas: How civic capacity contributes to neighborhood resilience', City and Community, 17(1), 65-86. doi: 10.1111/cico.12287

Pavolini, E., M. León, A.M. Guillén and U. Ascoli (2015), 'From austerity to permanent strain? The EU and welfare state reform in Italy and Spain', Comparative European Politics, 13(1), 56-76.

Peck, J. (2012), 'Austerity urbanism: American cities under extreme economy', City, 16(6), 626-55. doi: 10.1080/13604813.2012.734071

Pierson, P. (2000), 'Increasing returns, path dependence, and the study of politics', American Political Science Review, 94(2), 251-67.

Pradel-Miquel, M. (2017), 'Crisis, (re-)informalization processes and protest: The case of Barcelona', Current Sociology, 65(2), 209-21. doi: org/10.1177/0011392116657291

Pradel-Miquel, M. and M. Martí-Costa (2012), 'The knowledge city against urban creativity? Artists' workshops and urban regeneration in Barcelona', European Urban and Regional Studies, 19(1), 92-108. doi: 10.1177/0969776411422481

Rosol, M. (2012), 'Community volunteering as neoliberal strategy? Green space production in Berlin', Antipode, 44(1), 239-57. doi: 10.1111/j.1467-8330.2011.00861.x

Sánchez Belando, M.V. (2017), 'Building alternatives to the creative turn in Barcelona: The case of the socio-cultural centre Can Batllo', City, Culture and Society, 8, 35-42. https://doi.org/10.1016/j.ccs.2016.11.001

Scott, J.C. (1989). 'Everyday forms of resistance', Copenhagen Journal of Asian Studies, 4(1), 33-62. doi: 10.22439/cjas.v4i1.1765

Semprebon, M. and S. Vicari Haddock (2016), 'Innovative housing practices involving immigrants: The case of self-building in Italy', Journal of Housing and the Built Environment, 31(3), 439-55.

Silver, H.F. (2019), 'Social exclusion', in A.M. Orum (editor in chief), D.R. Judd, M. García Cabeza, P. Choon-Piew and B. Roberts (Eds), The Wiley-Blackwell Encyclopedia of Urban and Regional Studies, Hoboken: Wiley-Blackwell, pp. 1901-7.

Standing, G. (2014), A Precariat Charter: From denizens to citizens, London: Bloomsbury.

Swyngedouw, E. (2005), 'Governance innovation and the citizen: The Janus face of governance-beyond-the-state', Urban Studies, 42(11), 1991-2006. doi: $10.1080 / 00420980500279869$

Vaiou, D. and A. Kalandides (2016), 'Practices of collective action and solidarity: Reconfigurations of the public space in crisis-ridden Athens, Greece', Journal of Housing and the Built Environment, 31(3), 457-70.

van Berkel, R. and V. Borghi (2008), 'Review article: The governance of activation', Social Policy and Society, 7(3), 393-402.

Vicari Haddock, S. and C. Tornaghi (2013), 'A transversal reading of social innovation in European cities', in F. Moulaert, D. MacCallum, A. Mehmood and A. Hamdouch (Eds), The International Handbook on Social Innovation: Collective action, social 
learning and transdisciplinary research, Cheltenham, UK and Northampton, MA, USA: Edward Elgar Publishing, pp. 264-74.

Vitale, T. (2007), 'Olinda, o della difficile costruzione di un pubblico', in L. Pellizzoni (Ed.), Democrazia locale: apprendere dall'esperienza, Gorizia: Istituto di Sociologia Internazionale di Gorizia, Dipartimento di Scienze dell'Uomo, Università di Trieste, pp. 133-40.

Zavos, A., P. Koutrolikou and D. Siatitsa (Eds) (2018), Changing Landscapes of Urban Citizenship: Southern Europe in times of crisis, London: Routledge. 